\title{
DETERMINAN KEPUASAN KEUANGAN PELAKU UMKM
}

\author{
Abdul Wahab, Ida Rahayu Aprilla, Andi Mulia \\ Universitas Islam Negeri Alauddin Makassar \\ Jl. H.M. Yasin Limpo No.36, Gowa \\ abdul.wahab@uin-alauddin.ac.id
}

\begin{abstract}
:
The existence of Micro, Small, and Medium Enterprises, or commonly abbreviated as MSMEs, is expected to contribute quite well to efforts to tackle economic problems that are often faced, such as high levels of poverty, large numbers of unemployed, income distribution inequality. The role of MSMEs in Indonesia must be able to reduce the level of unemployment, which is increasing from year to year, alleviating poverty by helping poor people and income distribution that can improve the lives of people who have limitations, especially in financial matters. This study aims to determine the effect of gender (gender), income, and financial knowledge on financial satisfaction. The results of this study indicate that the variables of gender (gender), revenue, and financial knowledge simultaneously influence financial satisfaction. If partially tested, the gender variable statistically insignificant affects financial satisfaction. While the income and financial knowledge variables somewhat influence financial satisfaction.
\end{abstract}

\begin{abstract}
Abstrak: Keberadaan Usaha Mikro Kecil dan Menengah atau biasa disingkat dengan UMKM, diharapkan dapat memberikan konstribusi yang cukup baik terhadap upaya penanggulangan masalah-masalah ekonomi yang sering dihadapi seperti tingginya tingkat kemiskinan, besarnya jumlah pengangguran, ketimpangan distribusi pendapatan. Peranan UMKM di Indonesia harus dapat mengurangi tingkat pengangguran yang semakin bertambah dari tiap tahun, menanggulangi kemiskinan dengan membantu masyarakat yang kurang mampu dan pemerataan pendapatan yang dapat memperbaiki kehidupan masyarakat yang memiliki keterbatasan khususnya dalam masalah keuangan. Penelitian ini bertujuan untuk mengetahui pengaruh faktor jenis kelamin (gender), pendapatan dan pengetahuan keuangan terhadap kepuasan keuangan. Hasil penelitian ini menunjukkan bahwa variabel jenis kelamin (gender), pendapatan dan pengetahuan keuangan berpengaruh secara simultan terhadap kepuasan keuangan. Apabila diuji secara parsial variabel jenis kelamin (gender) tidak berpengaruh terhadap kepuasan keuangan. Sedangkan variabel pendapatan dan pengetahuan keuangan berpengaruh secara parsial terhadap kepuasan keuangan.
\end{abstract}

Kata Kunci: Kepuasan keuangan, UMKM, Gender, Literasi Keuangan

\section{PENDAHULUAN}

Peranan UMKM di Indonesia harus dapat mengurangi tingkat pengangguran yang semakin bertambah dari tiap tahun, menanggulangi kemiskinan dengan membantu masyarakat yang kurang mampu dan pemerataan pendapatan yang dapat memperbaiki kehidupan masyarakat yang memiliki keterbatasan khususnya dalam masalah keuangan. Pembangunan dan pertumbuhan UMKM merupakan salah satu penggerak yang krusial bagi pembangunan dan pertumbuhan ekonomi di banyak 
negara di dunia. Karakteristik yang melekat pada UMKM bisa merupakan kelebihan atau kekuatan yang justru menjadi penghambat perkembangan ekonomi (economic growth constraints).

Secara umum, Usaha Mikro Kecil Menengah (UMKM) memberikan kontribusi terhadap Pendapatan Domestik Bruto (PDB). Angka yang tercatat pada awal tahun 2017 mencapai 61,41 \%. Namun, pada bulan agustus beberapa pengamatan memperediksi bahwa kontribusi UMKM terhadap PDB akan menurun disebabkan oleh lesunya sektor perdagangan dan perindustrian. Ekonomi Indonesia tahun 2017 tumbuh sebesar 5,07\% lebih tinggi dibandingkan pencapaian pada tahun 2016 sebesar 5,03. Dari sisi produksi, pertumbuhan tertinggi dicapai Lapangan Usaha Informasi dan Komunikasi sebesar 9,81\%. Dari sisi pengeluaran pertumbuhan tertinggi dicapai oleh Komponen Ekspor Barang dan Jasa sebesar 9,09\% (BPS, 2017).

Menurut Laporan Kinerja Instansi Pemerintah (LAKIP) Dinas Koperasi dan Usaha Kecil Menengah Pemerintah Kota Makassar, salah satu hal yang dianggap masih menjadi kendala ataupun masalah yang dirasakan oleh sebagian besar pelaku UMKM adalah terbatasnya kemampuan enterpreneur pelaku UMKM serta masih kurangnya inovasi dalam pengembangan usaha sehingga membatasi pencapaian kinerja usaha (laba) bisnis.

Seluruh manusia memiliki tujuan hidup yang ingin mereka capai. Tujuan hidup yang ingin dicapai berbeda-beda antara individu satu dengan individu lainnya. Manusia akan merasa bahagia apabila telah mendapatkan sesuatu yang diinginkannya. Setiap manusia ingin mencapai kebahagiaan hidup baik kebahagiaan dunia maupun kebahagiaan akhirat. Kebahagiaan hidup di dunia dapat diindikasikan pada berbagai macam ukuran yang berbeda tergantung setiap individu masing-masing. Dalam bidang keuangan, kebahagiaan hidup dapat dirasakan apabila seseorang telah mencapai financial satisfaction (Hartina, 2017: 3).

Menurut Zimmerman (1995:8), Kepuasan finansial menunjukkan kepuasan seseorang dengan kondisi keuangan saat ini. Sedangkan menurut Mugenda (1998:79) Financial satisfaction merupakan evaluasi kepuasan tiap-tiap individu terhadap kondisi keuangan pribadi.

Jenis kelamin (gender) merupakan perbedaan biologis antara laki-laki dan perempuan sejak dilahirkan. Sedangkan menurut Wisnu (2011:16) jenis kelamin adalah suatu konsep karakteristik yang membedakan seseorang antara laki-laki dan perempuan dalam berperilaku. Seorang perempuan biasanya memiliki sifat yang lebih halus apabila dibandingkan laki-laki, sebab laki-laki cenderung menggunakan nalurinya apabila dibandingkan dengan perempuan yang lebih menggunakan perasaannya sehingga tingkah laku seorang perempuan akan berbeda halnya dengan laki-laki (Peter G.S, 2013: 182).

Menurut Weinberg (2001:270) income adalah pendapatan yang diterima baik berupa kas maupun bukan kas, yang dapat langsung digunakan untuk dapat dibelanjakan sehingga dapat meringankan beban rumah tangga. Secara umum, komponen income adalah kas dari pekerjaan utama maupun bukan pekerjaan utama, dividen, bunga tabungan, royalti, dana pensiun, dan bonus. Richard A. Easterlin (2001:467), dalam penelitiannya menunjukkan bahwa pendapatan berpengaruh 
terhadap kepuasan keuangan. Hal ini berarti semakin tinggi pendapatan yang diterima keluarga maka semakin tinggi pula peluang mengalami kepuasan keuangan.

Orang yang memiliki pengetahuan keuangan yang lebih baik akan memiliki perilaku keuangan seperti membayar semua tagihan tepat waktu, membukukan pengeluaran setiap bulan, dan memiliki dana darurat. Seseorang dapat memperoleh pengetahuan karena menyimpan dan mengumpulkan kekayaan, atau memungkinkan karena memiliki pengalaman keuangan keluarga. Financial knowledge adalah kemampuan untuk memahami, menganalisis dan mengelola keuangan untuk membuat suatu keputusan keuangan yang tepat agar terhindar dari masalah keuangan. Menurut Volpe (1998:110), financial knowledge merupakan pemahaman seseorang dalam general personal finance knowledge, pengetahuan mengenai investasi, pengetahuan mengenai saving. Yopie Kurnia Erista Halim dan Dewi Astuti (2015:22), dalam penelitiannya menunjukkan bahwa pengetahuan keuangan berpengaruh secara signifikan terhadap kepuasan keuangan. Semakin tinggi tingkat financial knowledge seseorang maka cenderung akan lebih puas dengan kondisi finansial.

Tidak dapat dipungkiri bahwa semua manusia menginginkan akan kehidupan yang sejahtera. Sejahtera dalam berbagai kehidupan, baik di masa sekarang lebihlebih di masa yang akan datang yang ditandai dengan ketersediaan aset keuangan yang cukup. Kebutuhan dapat terpenuhi. Oleh karena itu, mengelola keuangan secara tepat merupakan salah satu hal yang penting untuk keberlangsungan kehidupan agar kepuasan keuangan dapat terpenuhi.

Pengelolaan keuangan merupakan hal yang penting terutama para pelaku usaha, termasuk pelaku ekonomi rakyat, yang mayorits berskala Usaha Mikro, Kecil dan Menengah (UMKM). Kerry (2010) menyatakan bahwa peranan UMKM sangat strategis dalam perekonomian sebagai salah satu kekuatan pendorong utama dalam kegiatan ekonomi. Setelah melakukan pengamatan di kota Makassar ternyata masih banyak pelaku UMKM yang memiliki kelemahan dalam masalah keuangan. Diantaranya yaitu kurang baik dalam melakukan pengelolaan keuangan atau melek keuangan yang mengakibatkan kurangnya kepuasan keuangan (Dinas Koperasi dan UKM Kota Makassar).

\section{Behavioral Finance Theory}

\section{TINJAUAN TEORETIS}

Behavioral Finance Theory merupakan suatu ilmu yang mempelajari mengenai bagaimana manusia dalam mengambil tindakan dalam pengambilan keputusan dalam melakukan investasi dari informasi yang diperolehnya. Selain itu, investor tidak selalu rasional dalam pengambilan keputusan. Behavioral Finance Theory tidak hanya selalu bersifat rasional tetapi juga dipengaruhi oleh ketidakrasionalan yaitu psikologi (Wiryaningtyas, 2016:340).

Teori ini menyatakan bahwa ada pengaruh psikologis yang memengaruhi investor dalam pengambilan keputusan, terkadang emosi, sifat, pengetahuan dan hal sebagainya yang mengakibatkan investor tidak selalu rasional dalam pengambilan keputusan. Teori ini pada prinsipnya hendak mengkritik teori keuangan tradisional. 


\section{Subjective Well Being Theory (SWB)}

Subjective Well Being Theory (SWB) yang dikemukakan oleh Carol D. Ryff (1989) yang membangun konsep kesejahteraan psikologis dengan menganalisis teori-teori kesehatan mental (psikologis) seseorang yang pernah ada sebelumnya, termasuk Subjective Well Being Theory (SWB). Beberapa faktor terkuat yang memengaruhi SWB adalah kesehatan, kekayaan, dan akses pendidikan. Adapun faktor demografi yang dapat memengaruhi kesejahteraan subjektif, diantaranya yaitu : pendapatan, jenis kelamin dan juga pernikahan. Pendapatan menjadi hal utama yang sangat diperhatikan seseorang khususnya dalam pekerjaan dan kehidupan pada umumnya.

\section{Financial Satisfaction}

Menurut Zimmerman (1995:8), Kepuasan finansial menunjukkan kepuasan seseorang dengan kondisi keuangan saat ini. Sedangkan menurut Mugenda (1998) Financial satisfaction (kepuasan keuangan) merupakan evaluasi kepuasan tiap-tiap individu terhadap kondisi keuangan pribadi. Kepuasan keuangan berhubungan secara keseluruhan terhadap kesejahteraan psikologis yang dirasakan seseorang (Norvilitis, 2003). Kepuasan keuangan adalah situasi mengenai tingkat kepuasan terhadap kondisi ekonomi seseorang (Archuleta, Dale dan Spam, 2013).

Menurut Toscano ( 2006:221) financial satisfaction adalah kepuasan sesorang terhadap kondisi keuangan pribadi. Oleh karena itu, kepuasan keuangan merupakan salah satu komponen dari kehidupan yang ditandai dengan ketercukupan aset keuangan. Seseorang yang berpenghasilan cukup untuk memenuhi kebutuhan hidupnya, mungkin merasa puas dengan kondisi keuangan yang dimiliki ( Sheng, Kiak, dan Soon, 2013:54). Berpijak pada definisi tersebut tampak bahwa mencapai atau tidak mencapai kepuasan keuangan ditentukan oleh bagaimana mengelola uang. Selain daripada itu tampak bahwa kepuasan keuangan merupakan salah satu kewajiban bagi siapa saja untuk mewujudkannya.

\section{Jenis Kelamin (Gender)}

Byrne (2000:68) mendefinisikan bahwa gender merupakan sebagian dari konsep diri yang melibatkan identifikasi individu sebagai seorang laki-laki atau perempuan. Secara umum, pengertian gender adalah perbedaan yang tampak antara laki-laki dan perempuan apabila dilihat dari nilai dan tingkah laku. Dari beberapa definisi tersebut, dapat disimpulkan bahwa jenis kelamin (gender) adalah perbedaan biologis antara laki-laki dengan perempuan yang dilihat dari nilai dan tingkah laku.

\section{Pengetahuan Keuangan}

Astuti (2015:29) pengetahuan keuangan adalah kemampuan untuk memahami dan mengelola keuangan untuk membuat suatu keputusan keuangan yang tepat agar terhindar dari masalah keuangan. Orang yang memiliki pengetahuan keuangan yang lebih baik akan memiliki perilaku keuangan seperti membayar semua tagihan tepat waktu, membukukan pengeluaran setiap bulan, dan memiliki dana darurat. Seseorang dapat memperoleh pengetahuan karena melakukan menyimpan dan mengumpulkan kekayaan, atau memungkinkan karena memiliki pengalaman keuangan keluarga. Financial knowledge adalah kemampuan untuk memahami, 
menganalisis dan mengelola keuangan untuk membuat suatu keputusan keuangan yang tepat agar terhindar dari masalah keuangan.

\section{Lokasi dan Waktu Penelitian}

\section{METODE PENELITIAN}

Lokasi dalam penelitian ini yaitu di Kota Makassar. Penelitian ini dikhususkan untuk penduduk Kota Makassar yang memiliki Usaha Mikro Kecil Menengah (UMKM). Jumlah UMKM mencapai 16.428 yang bergerak pada beragam sektor dan tersebar di 15 kecamatan di Kota Makassar (Dinas Koperasi dan UKM Kota Makassar, 2018).

\section{Populasi dan Sampel}

Populasi adalah generalisasi yang terdiri dari objek atau subjek yang memilki kualitas dan karakteristik tertentu yang ditetapkan oleh peneliti untuk dipelajari kemudian ditarik kesimpulannya (Sugiyono, 2014: 120). Populasi dalam penelitian ini yaitu penduduk Kota Makassar yang memiliki Usaha Mikro Kecil Menengah (UMKM). Jumlah UMKM mencapai 16.428 yang bergerak pada beragam sektor dan tersebar di 15 kecamatan di Kota Makassar (Dinas Koperasi dan UKM Kota Makassar, 2018).

Sampel adalah bagian dari jumlah populasi (Sugiyono, 2014:125). Adapun tekhnik penarikan sampel dalam penelitian ini adalah seluruh industri usaha kecil yang tercatat di Dinas Koperasi dan UKM. Sampel penelitian akan dipilih secara acak sederhana (simple random sampling), dimana semua usaha kecil memperoleh kesempatan yang sama untuk dijadikan sampel. Untuk mendapatkan besaran sampel yang dapat mewakili populasi, Malhotra (1993) memberikan panduan ukuran sampel yang diambil dapat ditentukan dengan cara mengalikan jumlah variabel atau indikator yang digunakan dalam penelitian dengan 5 sampai 10 jumlah indikator setiap variabel yang digunakan (Indrawan \& Yaniawati, 2014: 130). Dengan demikian, jumlah sampel dalam penelitian ini adalah 75 sampel.

\section{Instrumen Penelitian}

Instrumen penelitian yaitu alat yang digunakan dalam membantu pengumpulan data. Instrumen yang digunakan dalam penelitian ini yaitu dengan menggunakan kuisioner (angket) yang berisi daftar pertanyaan atau pernyataan yang diberikan kepada pelaku UMKM di Kota Makassar (responden). Responden hanya dapat memilih jawaban yang telah disediakan oleh peneliti. Adapun skala pengukuran yang digunakan dalam penelitian ini adalah skala likert 1-5 yaitu:

\begin{tabular}{cl}
\hline Skor & \multicolumn{1}{c}{ Pernyataan } \\
\hline 1 & Sangat Tidak Setuju (STS) \\
\hline 2 & Tidak Setuju (TS) \\
\hline 3 & Ragu-ragu (R) \\
\hline 4 & Setuju (S) \\
\hline 5 & Sangat Setuju (SS) \\
\hline
\end{tabular}




\section{Teknik Pengolahan dan Analisis Data}

Metode pengolahan data yang digunakan adalah model regresi berganda dengan bentuk persamaan sebagai berikut:

$$
\mathrm{Y}=\mathrm{a}+\mathrm{b}_{1} \mathrm{X}_{1}+\mathrm{b}_{2} \mathrm{X}_{2}+\mathrm{b}_{3} \mathrm{X}_{3}+\mathrm{e}
$$

Dimana

$$
\begin{array}{ll}
\mathrm{Y} & =\text { Kepuasan keuangan } \\
\mathrm{X}_{1} & =\text { Gender } \\
\mathrm{X}_{2} & =\text { Pendapatan } \\
\mathrm{X}_{3} & =\text { Pengetahuan Keuangan } \\
\mathrm{a} & =\text { Konstanta } \\
\mathrm{b} & =\text { Koefisien regresi } \\
\mathrm{e} & =\text { error term }
\end{array}
$$

Penggunaan model regresi sebagai alat analisis utama membawa konsekuensi dilakukannya pengujian terhadap data yang digunakan, spesifikasi model, dan pengujian hipotesis. Pengujian data dalam penelitian ini menggunakan uji validitas dan reliabilitas.

Sedangkan untuk pengujian spesifikasi model menggunakan uji Asumsi Klasik yang meliputi uji normalitas dengan melihat normal probability plot data, uji multikolinearitas dengan melihat Variance Inflation Factor (VIF), uji autokorelasi dengan melihat nilai dari Durbin-Watson, dan uji heteroskedastisitas menggunakan indikator scatter plot.

Adapun pengujian hipotesis menggunakan kriteria Koefisien Determinasi $\left(\mathrm{R}^{2}\right)$, F-test, dan t-test.

\section{PEMBAHASAN}

Analisis uji regresi linear berganda bertujuan untuk mengetahui suatu variabel dependen (kepuasan keuangan) berdasarkan variabel independen (gender, pendapatan, dan pengetahuan keuangan) dalam suatu persamaan linear. Adapun hasil uji persamaan regresi dapat dilihat pada tabel berikut ini.

Tabel 1. Persamaan Regresi

\begin{tabular}{lcccc}
\hline \multirow{2}{*}{ Model } & \multicolumn{2}{c}{ Unstandardized Coefficient } & \multirow{2}{*}{ t } & \multirow{2}{*}{ Sig. } \\
\cline { 2 - 3 } & Beta & Std. Error & & \\
\hline Constant & 1.464 & 0.528 & 2.774 & 0.007 \\
\hline Gender & -0.172 & 0.266 & -0.647 & 0.520 \\
\hline Pendapatan & 0.353 & 0.099 & 3.564 & 0.001 \\
\hline Pengetahuan Keuangan & 0.372 & 0.124 & 3.002 & 0.004 \\
\hline
\end{tabular}

Hasil regresi tersebut setelah melalui tahapan pengujian validitas dan reliabilitas. Kedua uji tersebut memberikan hasil bahwa data yang digunakan valid dan realibel. Oleh karena itu, maka dapat dilakukan pengujian terhadap spesifikasi model persamaan penelitiannya. 
Pengujian spesifikasi model menggunakan pengujian Asumsi Klasik, sesuai dengan rule of thumbs yang menjadi standar minimal dari teknik regresi ordinary least square (OLS). Pertama, uji Normalitas. Uji normalitas bertujuan untuk menguji apakah dalam model regresi, variabel dependen (gender, pendapatan dan pengetahuan keuangan) dan variabel independen (kepuasan keuangan) memiliki distrribusi normal. Uji normalitas dengan grafik normal P-Plot akan membentuk satu garis lurus diagonal. Kemudian ploting data akan dibandingkan garis diagonal. Jika distribusi normal garis yang menggambarkan data sesungguhnya yang akan mengikuti garis diagonalnya.

Kedua, uji Multikolinearitas. Uji multikolinieritas (kolinearitas ganda) dilakukan dengan menghitung nilai Variance Inflation Factor (VIF) dari tiap-tiap variabel independen. Apabila nilai tolerance $<0,10$ atau sama dengan nilai VIF $>10$ maka terdapat data multikolinieritas yang tidak dapat ditoleransi (Ghozali, 2007: 103). Nilai tolerance dari semua variabel penelitian yang digunakan mendapatkan nilai < 0,10 dan nilai VIF > 10. Sehingga disimpulkan bahwa tidak terjadi multikolinearitas.

Ketiga, uji Heterokedastisitas. Cara untuk mendeteksi heteroskedastisitas adalah dengan melihat scatter plot antara standaedized residual (SRESID) terhadap standardized predicted value (ZPRED). Hasil pengujian dan ilustrasi scatter plot memperlihatkan bahwa titik-titik menyebar secara acak dan membentuk pola yang tidak teratur, sehingga dapat disimpulkan bahwa tidak terjadi heteroskedastisitas.

Keempat, uji Autokorelasi. Untuk mendeteksi apakah residual terdapat korelasi yang tinggi dapat dilihat dengan uji Durbin-Watson (DW test) yaitu dengan membandingkan nilai Durbin Watson (DW) hitung dengan DW tabel. Hasil pengujian Durbin-Watson menunjukkan bahwa tidak terdapat autokorelasi.

Setelah pengujian spesifikasi model penelitian, selanjutnya dilakukan pengujian terhadap hipotesis yang diajukan. Pertama, Koefisien Determinasi $\left(\mathrm{R}^{2}\right)$. Koefisien determinasi $\left(\mathrm{R}^{2}\right)$ digunakan untuk mengukur besar presentase dari variabel dependen (kepuasan keuangan) yang dapat dijelaskan oleh variabel independen (gender, pendapatan dan pengetahuan keuangan). Hasil perhitungan diperoleh nilai $\mathrm{R}^{2}$ sebesar 0,287 yang berarti bahwa 28,7 persen nilai dari variabel kepuasan keuangan dijelaskan oleh variabel independen sedangkan sisanya sebesar 61,3 persen dijelaskan oleh variabel lain di luar model.

Kedua, uji-F atau uji simultan. Hasil pengujian menujukkan bahwa nilai signifikansi dari F-statistics adalah 0,000. Sehingga dapat disimpulkan bahwa variabel independen (gender, pendapatan dan pengetahuan keuangan) jika di uji secara simultan (bersama-sama) berpengaruh signifikan terhadap variabel dependen (kepuasan keuangan).

Ketiga, uji t yang dilakukan untuk mengetahui hubungan pengaruh variabel independen (gender, pendapatan dan pengetahuan keuangan) secara parsial (individu) terhadap variabel dependen (kepuasan keuangan). Berdasarkan hasil perhitungan dinyatakan bahwa hasil output SPSS tersebut variabel gender (X1) dengan tingkat signifikan diatas 0,05 yaitu 0,520 , variabel pendapatan (X2) dibawah 0,05 yaitu 0,01 dan variabel pengetahuan keuangan (X3) dibawah 0,05 yaitu 0,04.

Berdasarkan pada estimasi asil regresi persamaan struktural penelitian dapat dituliskan sebagai berikut: 


$$
\mathrm{Y}=1,464-0,172 \mathrm{X}_{1}+0,353 \mathrm{X}_{2}+0,372 \mathrm{X}_{3}
$$

Nilai konstanta sebesar 1,464 yang artinya apabila seluruh variabel independen atau ariabel $X$ nilainya 0 , maka nilai $Y$-nya adalah 1,464 . Variabel $b_{1}=-0,172$ artinya apabila gender mengalami kenaikan 1\% maka dapat disimpulkan bahwa tidak berpengaruh terhadap kepuasan keuangan. Variabel $b_{2}=0,353$ artinya apabila pendapatan mengalami kenaikan sebesar 1\% maka kepuasan keuangan akan meningkat sebesar 0,353 . Variabel $b_{3}=0,372$ artinya apabila pengetahuan keuangan mengalami kenaikan sebesar 1\% maka kepuasan keuangan akan meningkat sebesar 0,372.

Pengaruh Gender, Pendapatan, dan Pengetahuan Keuangan terhadap Kepuasan Keuangan Secara Simultan

Berdasarkan data dari hasil output yang diperoleh dari hasil penelitian menggunakan SPSS menunjukkan bahwa nilai signifikan dibawah 0,05 yaitu 0,000 dalam analisis regresi sehingga dapat disimpulkan bahwa variabel gender(X1), pendapatan (X2) dan pengetahuan keuangan (X3) berpengaruh secara simultan (bersama-sama) terhadap kepuasan keuangan (Y). Pendapatan bukanlah hal utama untuk mencapai kepuasan keuangan tetapi juga dibutuhkan pengetahuan keuangan dalam hal mengelola keuangan untuk mencapai kepuasan keuangan.

Penelitian ini mendukung teori yang digunakan yaitu behavioral finance theory yang menyatakan bahwa ada pengaruh psikologis yang memengaruhi seseorang dalam pengambilan keputusan, terkadang seseorang tidak rasional dalam pengambilan keputusan yang akan berdampak pada kondisi keuangannya. Pengetahuan keuangan dibutuhkan agar mampu mengelola keuangan secara baik dan benar. Berpengaruh secara simultan (bersama-sama) merupakan penemuan baru dari hasil penelitian ini, pada peneliti sebelumnya menggunakan faktor-faktor lain untuk menentukan kepuasan keuangan dan diuji secara parsial. Dengan demikian penelitian ini sesuai dengan hipotesis penelitian yang menyatakan jenis kelamin (gender), pendapatan dan pengetahuan keuangan berpengaruh secara signifikan terhadap kepuasan keuangan.

\section{Gender terhadap Kepuasan Keuangan}

Jenis kelamin (gender) merupakan perbedaan biologis antara laki-laki dan perempuan sejak dilahirkan. Sedangkan menurut Wisnu (2011) jenis kelamin adalah suatu konsep karakteristik yang membedakan seseorang antara laki-laki dan perempuan dalam berperilaku. Jenis kelamin dalam penelitian ini menggunakan variabel dummy, jenis kelamin laki-laki $=1$ sedangkan jenis kelamin perempuan $=0$.

Hasil pengolahan menggunakan menunjukkan hasil tingkat signifikansi berada diatas 0,05 yaitu 0,520 sehingga peneliti dapat menarik kesimpulan bahwa jenis kelamin (gender) tidak berpengaruh secara parsial terhadap kepuasan keuangan. Hal ini menunjukkan bahwa tidak ada perbedaan dalam hal mengelola keuangan antara laki-laki dan perempuan untuk mengalami kepuasan keuangan.

Menurut Zimmerman (1995:8), Kepuasan finansial menunjukkan kepuasan seseorang dengan kondisi keuangan saat ini. Sedangkan menurut Mugenda (1998) Financial satisfaction (kepuasan keuangan) merupakan evaluasi kepuasan tiap-tiap individu terhadap kondisi keuangan pribadi. Kepuasan keuangan berhubungan secara keseluruhan berhubungan terhadap kesejahteraan psikologis yang dirasakan seseorang (Norvilitis, 2003). Kepuasan keuangan adalah situasi mengenai tingkat 
kepuasan terhadap kondisi ekonomi seseorang (Archuleta, Dale dan Spam, 2013). Adapun faktor demografi yang dapat memengaruhi kesejahteraan subjektif, diantaranya yaitu : pendapatan, jenis kelamin dan juga pernikahan. Dengan demikian penelitian ini tidak sesuai dengan hipotesis penelitian yang menyatakan bahwa jenis kelamin (gender) berpengaruh terhadap kepuasan keuangan.

\section{Pendapatan terhadap Kepuasan Keuangan}

Berdasarkan UU Nomor 17 tahun 2000 mengenai perpajakan, definisi penghasilan adalah setiap tambahan kemampuan ekonomis yang diterima atau diperoleh yang digunakan untuk konsumsi atau menambah kekayaan. Menurut Weinberg (2001) income adalah pendapatan yang diterima baik berupa kas maupun bukan kas, yang dapat langsung digunakan untuk belanja sehingga dapat meringankan beban rumah tangga. Secara umum, komponen income adalah kas dari pekerjaan utama maupun bukan pekerjaan utama, dividen, bunga tabungan, royalti, dana pensiun, dan bonus. Dalam bisnis pendapatan adalah jumlah uang yang diterima oleh perusahaan dalam aktifitasnya yang berasal dari jumlah penjualan produk atau jasa kepada pelanggan.

Setelah melakukan penelitian di kota Makassar sebanyak 75 responden, dengan menggunakan kuisioner peneliti dapat menyimpulkan bahwa pendapatan berpengaruh secara parsial terhadap kepuasan keuangan. Berdasarkan hasil pengolahan data dengan menggunakan SPSS 25 menunjukkan hasil tingkat signifikansi dibawah 0,05 yaitu 0,01. Dengan demikian pendapatan merupakan salah satu faktor penentu untuk mencapai kepuasan keuangan. Semakin tinggi pendapatan seseorang maka semakin tinggi untuk mengalami kepuasan keuangan.

Hasil penelitian ini sejalan dengan hasil penelitian yang dilakukan oleh Richard A. Easterlin (2001:467), dalam penelitiannya menunjukkan bahwa pendapatan berpengaruh terhadap kepuasan keuangan. Hal ini berarti semakin tinggi pendapatan yang diterima keluarga maka semakin tinggi pula peluang untuk mengalami kepuasan keuangan. Oleh karena itu, perlu adanya upaya berkesinambungan untuk meningkatkan pendapatan. Dengan kata lain, menurunnya pendapatan individu berpeluang menurunkan kepuasan keuangan.

Penelitian ini juga sejalan dengan peneliti sebelumnya yaitu yang dilakukan oleh Delaney, Newman dan Nolan (2006) dengan hasil penelitiannya menemukan bahwa efek pendapatan keluarga berpengaruh secara signifikan terhadap kepuasan keuangan yang dialami keluarga. Hal ini berarti semakin tinggi pendapatan yang diterima oleh keluarga maka semakin tinggi pula peluang untuk mengalami kepuasan keuangan.

Penelitian ini juga sejalan dengan peneliti sebelumnya yaitu yang dilakukan oleh Siti Hartina Santoso (2017:78) dengan hasil penelitiannya menemukan bahwa income berpengaruh secara parsial terhadap kepuasan keuangan. Faktor income merupakan salah satu faktor yang penting untuk mengalami kepuasan keuangan. Posisi keuangan rumah tangga merupakan faktor penentu dari kepuasan hidup dan kesejahteraan finansial.

Menurut Hira dan Mugenda (1999), kepuasan keuangan (financial satisfaction) adalah gambaran umum dalam memprediksi kepuasan hidup, sebagai ukuran 
kesejahteraan subjektif (subjevtive well being-SWB). Menurut Mugenda (1998) Financial satisfaction (kepuasan keuangan) merupakan evaluasi kepuasan tiap-tiap individu terhadap kondisi keuangan pribadi. Hubungan antara pendapatan dan kebahagiaan seseorang merupakan salah satu mata pelajaran yang dibahas dalam literature mengenai kesejahteraan subjektif (SWB). Beberapa faktor terkuat yang memengaruhi SWB adalah kesehatan, kekayaan, dan akses pendidikan. Adapun faktor demografi yang dapat memengaruhi kesejahteraan subjektif, diantaranya yaitu : pendapatan, jenis kelamin dan juga pernikahan.

Pendapatan menjadi hal utama yang sangat diperhatikan seseorang khususnya dalam pekerjaan dan kehidupan pada umumnya. Besarnya jumlah pendapatan yang diterima merupakan hal utama untuk memenuhi kebutuhan hidup yang terus meningkat dan gaya hidup yang konsumtif. Gaya hidup dan kebutuhan yang terus meningkat harus diseimbangkan dengan jumlah pendapatan yang diterima, jika tidak dapat menimbulkan perasaan ketidakpuasan yang akhirnya membuat seseorang tidak bahagia. Dengan demikian penelitian ini sesuai dengan hipotesis penelitian yang menyatakan bahwa pendapatan berpengaruh terhadap kepuasan keuangan.

\section{Pengetahuan Keuangan terhadap Kepuasan Keuangan}

Menurut (Astuti, 2015) pengetahuan keuangan adalah kemampuan untuk memahami dan mengelola keuangan untuk membuat suatu keputusan keuangan yang tepat agar terhindar dari masalah keuangan. Orang yang memiliki pengetahuan keuangan yang lebih baik akan memiliki perilaku keuangan seperti membayar semua tagihan tepat waktu, membukukan pengeluaran setiap bulan, dan memiliki dana darurat. Menurut Volpe (1998:110), financial knowledge merupakan pemahaman seseorang dalam general personal finance knowledge, pengetahuan mengenai investasi, pengetahuan mengenai saving.

Setelah melakukan penelitian di kota Makassar sebanyak 75 responden, dengan menggunakan kuisioner dapat disimpulkan bahwa pengetahuan keuangan berpengaruh secara parsial terhadap kepuasan keuangan. Berdasarkan hasil pengolahan data dengan menggunakan SPSS 25 menunjukkan hasil tingkat signifikansi dibawah 0,05 yaitu 0,04. Semakin tinggi tingkat pengetahuan keuangan seseorang maka cenderung untuk mengalami kepuasan keuangan yang baik.

Hasil penelitian ini sejalan dengan hasil penelitian yang dilakukan oleh Yopie Kurnia Erista Halim dan Dewi Astuti (2015:22), dalam penelitiannya menunjukkan bahwa pengetahuan keuangan berpengaruh secara signifikan terhadap kepuasan keuangan. Semakin tinggi tingkat financial knowledge seseorang maka cenderung akan lebih puas dengan kondisi finansial. Robin Henager dan Sophia T Anong (2014) dengan hasil penelitiannya menunjukkan bahwa financial literacy mempunyai pengaruh terhadap kepuasan keuangan.

Hasil penelitian ini sejalan dengan hasil penelitian yang dilakukan oleh Siti Hartina Santoso (2017:79) dengan hasil penelitian menyatakan bahwa pengetahuan keuangan berpengaruh secara parsial terhadap kepuasan keuangan. Pengetahuan keuangan merupakan perilaku yang positif untuk menentukan keputusan yang disebabkan adanya pengetahuan mengenai keuangan yang dapat menentukan tingkat kepuasan keuangan. 
Penelitian ini mendukung teori yang digunakan yaitu teori perilaku keuangan (behavioral finance theory), dalam penelitian menunjukkan bahwa seseorang yang memiliki pengetahuan keuangan yang baik, mampu mengelola keuangannya secara baik akan lebih cenderung untuk mengalami kepuasan keuangan sehingga akan berdampak positif terhadap kekayaan yang dimilikinya. Dengan demikian hasil penelitian ini sejalan dengan hipotesis penelitian yang menyatakan bahwa pengetahuan keuangan berpengaruh terhadap kepuasan keuangan.

\section{PENUTUP}

Penelitian ini bertujuan untuk mengetahui pengaruh variabel independen (gender, pendapatan dan pengetahuan keuangan) terhadap variabel dependen (kepuasan keuangan) pada pelaku UMKM di kota Makassar. Berdasarkan hasil analisis data regresi dalam penelitian ini, maka dapat ditarik kesimpulan sebagai berikut:

1. Jenis kelamin (gender), pendapatan dan pengetahuan keuangan berpengaruh secara simultan terhadap kepuasan keuangan, hal ini berdasarkan data yang diperoleh dari hasil penelitian menggunakan SPSS bahwa nilai signifikan dibawah 0,05 yaitu 0,000. Jadi, dapat ditarik kesimpulan bahwa hipotesis H1 diterima.

2. Jenis kelamin (gender) tidak berpengaruh secara signifikan terhadap kepuasan keuangan, ini berarti bahwa tidak terdapat perbedaan untuk mengalami tingkat kepuasan keuangan antara laki-laki dan perempuan, dibuktikan dengan tingkat signifikansi berada diatas 0,05 yaitu 0,520. Jadi, dapat ditarik kesimpulan bahwa hipotesis $\mathrm{H} 2$ adalah ditolak.

3. Pendapatan berpengaruh positif dan signifikan terhadap kepuasan keuangan dibuktikan dengan hasil tingkat signifikansi dibawah 0,05 yaitu 0,01. Dengan meningkatnya pendapatan yang diterima seseorang atau yang diperoleh maka akan meningkatkan pula peluang untuk merasakan kepuasan keuangan. Jadi, dapat ditarik kesimpulan bahwa hipotesis H3 diterima.

4. Pengetahuan keuangan berpengaruh positif dan signifikan terhadap kepuasan keuangan dibuktikan hasil pengolahan data menunjukkan hasil tingkat signifikansi dibawah 0,05 yaitu 0,04. Jadi, dapat ditarik kesimpulan bahwa hipotesis H4 diterima.

\section{DAFTAR PUSTAKA}

Ayuni R. P dan Asrori. 2018. Determinan Literasi Finansial Dengan Gender Sebagai Variabel Moderasi. Economic Education Analysis Journal. Badan Pusat Statistik. 2017. Keadaan Ketenagakerjaan. Jakarta, ID: Badan Pusat Statistik.

Budiono, Tania. 2014. Keterkaitan Financial Attitude, Financial Behavior \&Financial Knowledge Pada Mahasiswa. 
Chandra, Jesslyn Winata dan Gesti. 2015. Memarista. Faktor - Faktor yang Memengaruhi Financial Satisfaction pada Mahasiswa Universitas Petra. FINESTA, Vol.3, No, 2, (2015) 1-6.

Chen, H., \& Volpe, R. P. 1998. An Analysis of Personal Financial LiteracyAmong Colllege Students. Financial Services Reviews , 107- 128.

Danes, Sharon M. \& Haberman, Heather R. 2007. Teen Financial Knowledge, SelfEfficacy, and Behavior: A Gendered View. Financial Counseling and Planning Volume 18, Issue 2.

Danes, Sharon. M. 1994. Parental Perceptions Of Children's Financial Socialization. Financial Counseling and Planning, 5, 127-146.

Darokah, Marcham dan A.M Diponegoro. 2005. Peran Akhlak Terhadap Kebahagiaan Remaja Islam, Humanitas: Indonesian Psycological Journal, Vol.2, No.1, Januari 2005: 15-27.

Departemen Agama RI. 2010. Al- Qur'an dan terjemahan. Bandung: CV Penerbit Diponegoro.

Grable, J. E., \& Joo, S. H. 2004. An Exploratory Framework Of The Determinants Of Financial Satisfaction. Multiple pages.

Herujito, Y. M. 2001. Dasar-dasar manajemen. Jakarta, ID: Grasindo.

Hira, Tahira K \& Mugenda Olive M. 1998. Predictors Of Financial Satisfaction: Differences Between Retirees And Non-retirees. Financial Counseling and Planning, Volume 9(2).

Kahneman, Daniel, Solvic, Paul and Amos Tversky. 1982. Judgment Under Uncertainty: Heuristics and Biases. Cambrige University Press.

Kuncoro, M,. 2013, Metode Riset untuk Bisnis dan Manajemen. Jakarta: Erlangga.

Leksikawan, Fadila Bester. 2009. Behavioral Finance dalam Pengambilan Keputusan Investasi Beresiko. Jurnal Manajemen.

Manurung, Adler Haymans. Teori Perilaku Keuangan (Behavioral Finance). Jurnal Manajemen keuangan.

Mason, C. L. J. dan Wilson, R. M. S. 2000. Conceptualising Financial Literacy. Loughborough University, Vol.7, No. 41, pp, 301-311.

Olsen, Robert A. 1998. Behavioral Finance and Its Implications for Stock-Price Volatility. Financial Analyst Journal, Vol.54, No.2

Parrotta, J. L., \& Johnson, P. J. 1998. The Impact Of Financial Attitudes And Knowledge On Financial Management And Satisfaction Of Recently Married Individuals. Journal of Financial.

Peter G.S. 2013. Financial Efficiacy dan Financial Satisfaction: ditinjau dari Perbedaan Gender. Jurnal Manajemen.

Richard A. Earsterlin 2001. Income and Happiness. The Economic Journal, 111 (Juli), 465-484. 
Robb, C. A., \& Woodyard, A. S. 2011. Financial Knowledge And Best Practice Behavior. Journal of Financial Counseling and Planning, 22(1), 60-70.

Shefrin, Hersh 2005. A Behavioral Approach To Asset Pricing. Elsevier Academic Press.

Sheng, Maecus S.J, Tan Kian Kiak, Thomson E.W.W.S. 2013. The Impact Of Demographic Factor And Financial Satisfaction On Bequest Motives Among Collage Elderly In Selangor, Malaysia. A Research Project Submitted In Partial Fulfilment Of The Requirement For The Degree Of Bachelor Of Economics (Hons) Global economics.

Sodiq, Amirus. 2015. Konsep Kesejahteraan Dalam Islam. Equilibrium, Vol.3, No. 2.

Sugiyono. 2007. Metode Penelitian Administrasi. Bandung: Alfabeta. Counseling and Planning.

Sugiyono. 2014. Metode Penelitian Bisnis. Bandung: Alfabeta.

Titus, P. M., Fanslow, A. M., \& Hira, T. K. 1989. Effect Of Financial Management Knowledge Of Household Money Managers On Behaviors And Financial Outputs. Journal of Vocational Home Economics Education, 7(1), 58-70.

Vera Toscano, Eperanza, Victoria A.M dan Rafael Serrano D.R. 2006. Building Financial Satisfaction. Social Indicators Research, 77:211-243.

Wiryaningtyas, Dwi Permatasari. 2016. Behavioral Finance dalam Pengambilan Keputusan. Prosiding Seminar Nasional.

Xiao, J. J. 1996. Effect Of Financial Income And Life Cycle Stages On Financial Asset Ownership. Journal of Financial Counseling and Planning, 7.

Xiao, Jing Jian, Tang, Chuanyl\& Shim, Soyoen. 2009. Acting For Happines: Financial Behavior and Life Satisfaction of College Students. Social Indicators Research May 2009, Volume 92, Issue, pp 53-68.

Yopie dan Dewi. 2015. Financial Stressors, Financial Behavior, Risk Tolerance, Financial Solvency, Financial Knowledge, dan Kepuasan Finansial. FINESTA Vol. 3, No. 1, (2015) 19-23.

Yuliani dan Isnurhadi. 2015. Analisis Perilaku Investor Individu Kota Palembang Dalam Pembelian Dan Penjualan saham. Proceding Sriwijaya Economic and Business Conference.

Zimmerman, S. L. 1995. Understanding Family Policy : Theories And Applications (2nd ed). Thousand Oaks: CA: Sage 